\title{
ADMINISTRAÇÃO DA INFORMAÇÃO
}

Rosa CORRÊA'

\section{RESUMO}

Apresentação da Estrutura Curricular Curso de Administração da Informação das Faculdades Integradas Tereza Martin.

Palavras-chave: Ensino de Ciência da Informação; Estrutura Curricular.

\section{ABSTRACT}

Report on the Information Management Curriculum of Faculdades Integradas Tereza Martin.

Key words: Information Management Curriculum.

As Faculdades Integradas Teresa Martin começaram a funcionar em 1971, mediante autorização do MEC, através do Decreto n ${ }^{\circ} 68.282 / 71$, de 25 de fevereiro daquele ano. Desde sua fundação, a instituição preocupou-se com o bairro e a região, mantendo sua biblioteca aberta à população, patrocinando atividades culturais, realizando convênios com órgãos públicos para prestação de serviços à comunidade. A partir de 1986 iniciou a publicação de sua revista TEMA, que mantém intercâmbio com instituições nacionais e estrangeiras.

Atualmente possui dois campus, com os seguintes cursos:

\section{Campus Teresa Martin}

- Administração com habilitação em Análise de Sistemas;
- Administração com habilitação em Administração da Informação;

- Ciências Contábeis;

- Letras (Licenciatura);

- Ciências com habilitação em Matemática;

- História (Licenciatura);

- Geografia (Licenciatura).

\section{Campus Pinheirense}

- Administração com habilitação em Marketing;

- Administração com habilitação em Comércio Exterior;

- Turismo;

- Pedagogia com habilitação em Orientação Educacional e Magistério;

- Estudos sociais com habilitação em História e Geografia (Licenciatura).

1. Professora de Organização da Informação Empresarial do curso de Administração da Informação Bibliotecária especialista em Museologia. 
O curso de Administração com habilitação em Administração da Informação foi criado em 1999. Caracteriza-se pela associação entre uma formação generalista na área de administração, complementada com um conjunto de habilidades específicas relacionadas à área da administração, no que concerne às questões relativas ao adequado tratamento da informação, como instrumento de suporte à tomada de decisões e como forma de permitir às organizações um maior poder de decisão.

O currículo foi planejado de forma a permitir uma fusão sinérgica de conteúdos: administração e biblioteconomia, permitindo a formação de um profissional que, sendo administrador, possua todas as bases que o tornem apto a planejar, organizar e gerir uma central de informação. Este profissional poderá atuar nas organizações como um gerente do sistema de informações, dimensão esta cada vez mais fundamental para a manutenção da competitividade das organizações.

O regime escolar é anual e o prazo para conclusão do curso é de, no mínimo, 4 (quatro) anos e, no máximo, 7 (sete) anos.

Finalizando, o administrador egresso das Faculdades Integradas Teresa Martin deverá possuir conhecimentos generalistas sobre todas as áreas da administração e correlatas, com qualificação específica para atuação na área da gestão da informação, com visão ampla sobre a problemática que o tema refere, bem como sua relevância para a atualidade e consciente sobre a importância da efetividade das ações profissionais para uma eficaz gestão dos negócios das organizações. Deverá estar apto a planejar, organizar e gerir uma central de informação e possuir características profissionais para poder atuar nas organizações como um gerente do sistema de informações. 